This item was submitted to Loughborough's Research Repository by the author.

Items in Figshare are protected by copyright, with all rights reserved, unless otherwise indicated.

\title{
Palestinians and pragmatic citizenship: negotiating relationships between citizenship and national identity in diaspora
}

PLEASE CITE THE PUBLISHED VERSION

http://www.sciencedirect.com/science/article/pii/S0016718507001029

\section{PUBLISHER}

(c) Elsevier

VERSION

AM (Accepted Manuscript)

LICENCE

CC BY-NC-ND 4.0

\section{REPOSITORY RECORD}

Mavroudi, Elizabeth. 2019. "Palestinians and Pragmatic Citizenship: Negotiating Relationships Between Citizenship and National Identity in Diaspora". figshare. https://hdl.handle.net/2134/8834. 
This item was submitted to Loughborough's Institutional Repository (https://dspace.lboro.ac.uk/) by the author and is made available under the following Creative Commons Licence conditions.

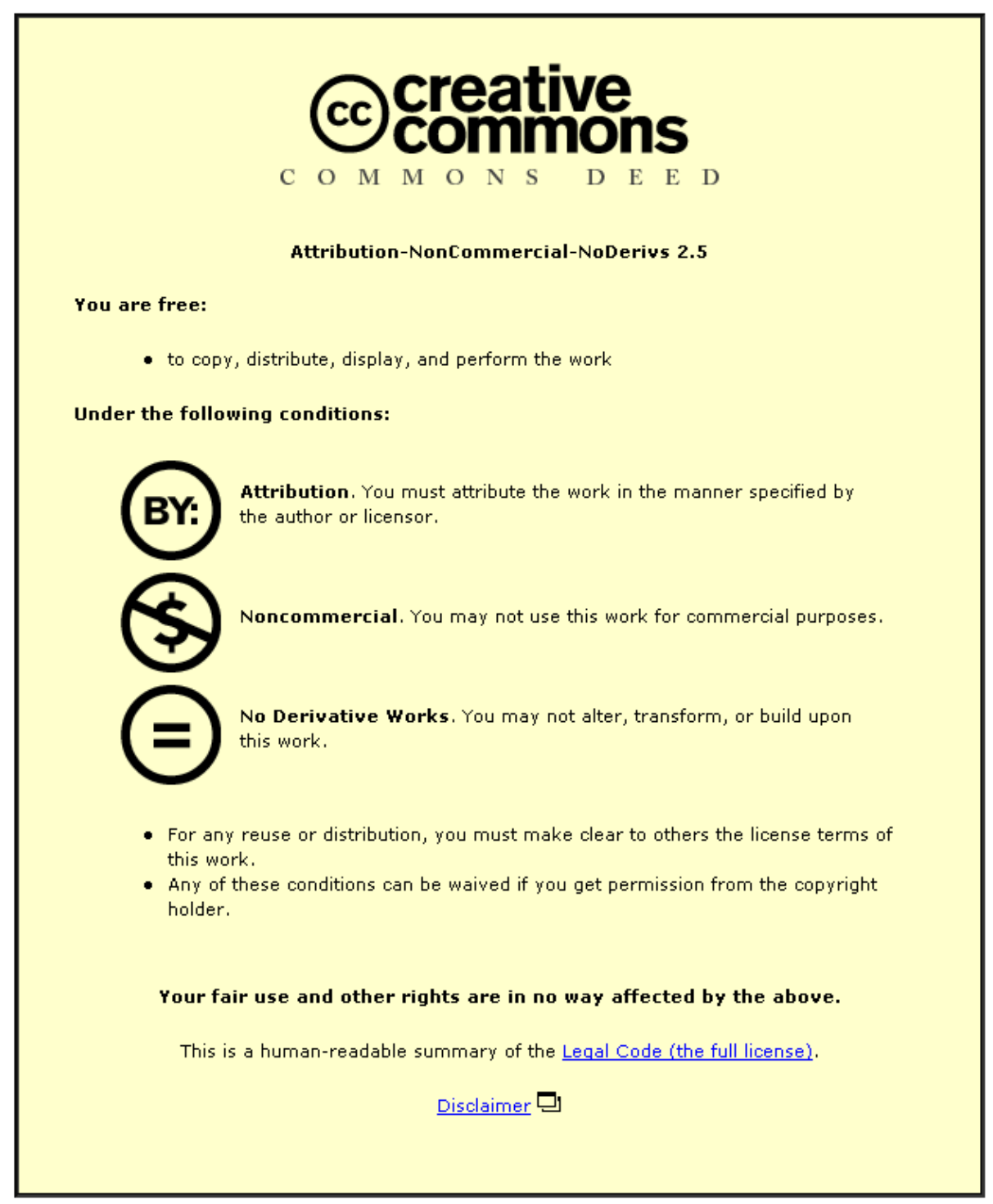

For the full text of this licence, please go to: http://creativecommons.org/licenses/by-nc-nd/2.5/ 


\title{
Palestinians and pragmatic citizenship: negotiating relationships between citizenship and national identity in diaspora
}

\begin{abstract}
This paper puts forward the notion of pragmatic citizenship and forms part of the ongoing re-appraisals of citizenship in relation to national identity in an attempt to make it more relevant and inclusive for those with complex identities, legal status and, in particular, the stateless. Using the case study of Palestinians in Athens to discuss relationships between citizenship, identity and statehood, this paper argues that the notion of pragmatic citizenship can be useful in such re-conceptualisations as it can take into account the potentially ambivalent and multiple feelings of belonging that migrants and those in diaspora may have. In the process it stresses that strong notions of belonging and attachment to a territorialised homeland do not have to be exclusive or problematic. The paper outlines the complexity of Palestinian legal status in Athens and the feelings of injustice statelessness can provoke; it then describes the process of Palestinian acquisition of pragmatic citizenship in Greece. However, the final section of the paper highlights that such a notion of citizenship can have positive repercussions in terms of inclusive visions of a future one-state solution to the Palestinian-Israeli conflict.
\end{abstract}

Keywords: Palestinians in diaspora, Athens, pragmatic citizenship, belonging, national identity, statelessness. 


\section{Palestinians and pragmatic citizenship: negotiating relationships between citizenship and national identity in diaspora}

\section{Introduction}

Relationships between citizenship and national identity are becoming increasingly complex as migrants and those in diaspora have multiple attachments, feelings of belonging and political loyalties. The notion of the decoupling of citizenship and identity (Isin and Wood, 1999) may help to describe such changes and forms part of ongoing reconceptualisations of citizenship in host societies. In particular, for migrants and those in diaspora, there may be a decoupling of citizenship and national identity whereby they obtain citizenship in the host country but continue to feel attached to their homeland. Such a de-territorialisation of the nation across state boundaries has triggered notions such as 'instrumental citizenship' and 'flexible citizens' (Ip et al 1997; Waters, 2003; Ong, 1999). Drawing on such ideas, this paper puts forward the notion of pragmatic citizenship $^{1}$ as a way to highlight the strategic element of migrant/diasporic citizenship acquisition that enables and allows for multiple feelings of belonging that are positioned at particular times/spaces for particular reasons. In the process, although it is inclusive, it does not deny people the right to belong and form strong attachments to place(s), particularly the homeland, which for those in diaspora can continue to be important.

Pragmatic citizenship forms part of the ongoing re-conceptualisation of citizenship in an attempt to make it more inclusive and relevant for migrants and those in diaspora who may have complex and ambiguous legal status, feelings of belonging and

\footnotetext{
${ }^{1}$ I am grateful to Cheryl McEwan for suggesting this term.
} 
relations to the state. At the same time, because it involves the acquisition of Westernstate citizenship it may be seen as a strategic form of citizenship that arises out of necessity, particularly for those who are stateless. Although there may be increasing cross-border connections that transgress state-controlled boundaries, such boundaries continue to exist. Those without formal citizenship status can feel marginalised and trapped. As a result, they may attach great importance to the acquisition of Western state citizenship. This paper examines such pragmatic citizenship and its relationships to national identity in relation to the Palestinian diaspora in Athens and their desire to attain Greek citizenship without letting go of their politicised belonging to Palestine and wish for self-determination and a solution to the Israeli-Palestinian conflict.

In relation to this, Stein and Swedenburg (2004: 11) have argued that: "the present-day (and past) conflict between Palestine and Israel illustrates the ongoing violence associated with the enduring exclusivist ideologies of the national”. Exclusionary notions of national identity and its relationship to citizenship within new states created as a result of self-determination may have significant implications for future citizenship laws, official membership of and inclusion within such newly formed states. As the notion of pragmatic citizenship does not necessarily demand full belonging to the host country, it can encourage strong feelings of belonging to the homeland and potentially lead to the normalising and accentuating of relationships between citizenship and national identity in a future state and/or homeland. However, as this paper will illustrate such perceptions do not have to be exclusive or problematic.

This paper is based on in - depth qualitative research carried out in 2003-2004, in which 54 Palestinians were interviewed informally using key gatekeepers who were 
accessed using the Palestinian Representation in Greece, the Parikia (or Palestinian community house) and snowballing techniques. These interviews were loosely structured around key themes but were open-ended enough for respondents to discuss issues they felt were important. If permission was given, interviews were tape-recorded and then transcribed. A system of coding around the key themes of home/belonging/national identity, politicisation/political activities, diasporic spaces and citizenship was then employed. Although the process of speaking to a wide cross-section of Palestinians in diaspora in Athens led to a variety of responses and opinions, this was seen in positive terms and highlighted the diversity of Palestinian experience in Athens. At the same time, it also allowed the exploration of difference as well as similarity.

The authors own positionality as non-Palestinian and non-Arab (and non-Arab speaking) was also important, as was the fact that research was being conducted for a British University; this had varying implications. On the one hand, some respondents felt honoured and happy that research was being conducted on what they thought and that their voices could be heard; on the other, some were suspicious and this resulted in the researcher having to justify and explain the research rationale and motives at length. Therefore, issues of trust were important; the nine month length of this project reflected the need to build up trust, acceptance and support over time. Not being able to speak to respondents in Arabic was also seen as a limitation; respondents were interviewed in either Greek or English, whichever they felt most comfortable and fluent in. However, this did not limit the choice of interviewee as on no occasion were participants excluded because of language. The main issue was the fact that they would have felt more at ease had Arabic been spoken and the nuances of certain notions might have been easier to 
discuss and articulate. The choice of interviewees for inclusion in this paper reflects their particular interests in and viewpoints on the relationships between citizenship and national identity; however, in the research itself, Palestinians from a wide range of backgrounds and with varying opinions were spoken to.

After a discussion on theoretical perspectives on citizenship and national identity as well as an outline of Palestinian legal status and perceptions of injustices in Greece, the paper focuses on the acquisition of pragmatic non-Palestinian citizenship and illustrates how many Palestinians remain emotionally attached to Palestine. The final part of this paper is perhaps the most important as it discusses the viewpoints of Palestinians in Athens with inclusive views on national identity and future statehood for Jews and Arabs in historical Palestine.

\section{Deconstructing citizenship and national identity}

Citizenship is a contested and complicated notion (Faulks, 2000). It can be seen as a set of practices and processes that allow individuals to construct, negotiate and position themselves spatially and temporally for strategic and legitimising purposes. There are a "staggering array of different policies and arrangements that further complicate any understanding of what precisely citizenship is” (Croucher 2004: 45). For example, Davis (1997: 3) has defined citizenship in western liberal democratic states in terms of the equal (civil, power-political, social service and material) resource rights afforded to citizens. Faist (2000: 202) has stressed that citizenship forms "a series of reciprocal transactions between a citizen and the state”, highlighting that citizenship is a two way process, where a citizen has duties as well as rights. However, duties should not necessarily depend on 
exclusive notions of identity. A decoupling of citizenship and identity (Isin and Wood 1999) does not necessarily mean that such rights and duties are ignored or are less important but highlights that citizenship needs to be less exclusive. At the same time, for migrants and those in diaspora, who want to obtain pragmatic citizenship, notions of jus soli and jus sanguinis citizenship, where the former refers to membership rooted in soil and the latter to membership rooted in blood (Croucher, 2004) influences how easy it is for them to be granted this citizenship. For the latter (as is the case in Greece), in particular, relationships between national identity and citizenship may be seen as exclusive as states may expect their citizens to belong exclusively to the nation-state.

Relationships between national identity and citizenship can be summarised as follows: "who gets defined as a 'true' citizen within the city-state or nation-state depends in part on who carries with them what is deemed to be the correct baggage of history, ethnicity, language and religion” (Painter and Philo, 1995: 112). Citizenship envisioned in such simpler or more traditional ways encourage definitions and validations based on official belonging to a country, which is linked to national identity. This can explain why people who have an ambiguous relationship with the 'nation-state' or who are not 'nationals', a concept that Castles and Davidson (2000: 84) call an "intrinsically particularistic and exclusionary category”, can be excluded or discriminated against.

In simplistic terms, it is often assumed that the people within a nation-state constitute a nation, and possess feelings of national identity and nationalism. According to Smith (1999: 37), nationalism is: 
an ideological movement for the attainment and maintenance of autonomy, unity and identity of a human population, some of whose members conceive it to constitute an actual or potential 'nation'. By a 'nation', I mean a named human population sharing a historical territory, common myths and memories, a mass public culture, a single economy and common rights and duties for all members.

The assumption that there is a naturalised and potentially exclusive relationship between territory, national identity and citizenship, whereby national identity is neatly located in a clearly demarcated and bounded nation-state can be seen as problematic. In relation to this, Wimmer and Glick Schiller (2002: 302) have noted that what they call 'methodological nationalism' is 'the assumption that the nation/state/society is the natural social and political form of the modern world”. It is such assumptions, they argue, that have deeply influenced academic theories within the social sciences and that also may explain why "the lack of a temporal and spatial fit between state and nation is one of the main causes of many of today's national conflicts” (Smith, 1999: 38). Despite the relevance of the homeland for diasporic and migrant populations, the fact that there are thousands of perceived homelands located in less than 200 nation-states could be seen as problematic if self-determination is seen as a right. According to Davis (1997: 24), the idea of a nation-state and self-determination has been given

international legal legitimisation with the proclamation of the FourteenPoint programme by Woodrow Wilson, 1918 and the proclamation of the Declaration on the Granting of Independence to Colonial Countries and 
Peoples by the United Nations, 1960. Established modern international legal terminology has since been predicated on the concept of 'nations' and 'peoples'... and the norm of the right of 'nations' and/or 'peoples' to selfdetermination which, in turn, is posited as the legitimising principle for the claim of the 'people' to sovereignty in the form of a 'nation-state' of its own.

Khalidi (1997: 209) illustrates the salience of such issues when he asks the openended question of whether the limited success in creating a Palestinian 'identity' will "finally allow the achievement of self-determination, statehood, and national independence the modern world has taught us is the "natural state" of peoples with an independent national identity like the Palestinians”. Statements such as this are justified by current understandings and uses of the relationships between national identity, citizenship and territorial nation-states, even if contemporary societies are much more complex and diverse in reality.

Although Palestinians in diaspora may still feel attached to a Palestinian homeland, the fact that many are acquiring pragmatic citizenship elsewhere and, therefore, may have multiple feelings of belonging, raises questions for their relationship with a future Palestinian state, especially if they want to return. This forms part of the wider debates around the de/re-territorialisation of the nation and the ability and need for migrants and those in diaspora to remain rooted and belong to their homelands and countries of origin even as they may acquire pragmatic citizenship elsewhere. 
Such imagined communities (Anderson, 1983) have been seen as an important aspect of national identity and nationalism. As a result, a strong symbolic attachment to one another and a territorialised state or homeland must be imagined in order to create a shared sense of belonging and sustain a nation-state, which can no longer be maintained by traditional face-to-face contact and which may also extend across borders, in the form of long-distance nationalism (Glick Schiller and Fouron, 2001; Skrbis, 1999), for example. Nationalism can also potentially (and unsurprisingly) lead, therefore, to what Gilroy (1999) has called 'ethnic absolutism' or extreme forms of nationalism that can be seen behind tragic processes such as ethnic cleansing and some homeland-orientated politics (Carter, 2005). As this paper will show, however, self-determination and the need for strong feelings of belonging to a nation and/or state do not have to be exclusive and can be based around more inclusive notions of belonging and citizenship.

\section{Pragmatic citizenship}

The acquisition of pragmatic citizenship forms part ongoing re-conceptualisations of citizenship. Citizenship is being critically reappraised in order to make it relevant to the needs of and more inclusive for people today, such as women (McEwan, 2000) and migrants (Croucher, 2004; Benhabib, 2004) who are being potentially excluded or marginalised. This may be particularly the case for migrants and those in diaspora who are stateless or whose citizenship status is ambiguous and/or decoupled from the national identity of the host country in which they reside. The decoupling of citizenship and national identity illustrates that they may have voluntary multiple attachments and affiliations, which may stretch beyond the borders of the state in which they are currently 
citizens. As Nagel and Staeheli (2004: 6, citing Mandaville 1999) note: “immigrant groups (or diasporas and transmigrants) are said to exist in a new global market of political loyalties, engaging in a complex politics of 'here and there' and resisting attempts by the state to "fix parameters of political community and territory" and to assimilate newcomers into a national's culture”.

As Nagel and Staeheli (2004: 4) also argue: "it is possible to claim identity as a citizen of a country and to negotiate membership within the bounds of 'belonging', even without claiming to 'be of' that country”, thus breaking the assumed congruity between citizenship, state and nation. In relation to this, Soysal (1998: 210, 209) has argued that "the idea of nation becomes insignificant, a mere trope of convenience for claims to collective rights and identity”. For Soysal, post-national membership is a more relevant notion, whereby "an identity politics energised by narratives of collective pasts and accentuated cultural differences, becomes the basis for participation and affords the means for mobilising resources in the national and world polities”. In a similar vein, Tambini (2001: 212) feels that 'post-national citizenship' is becoming more important as "the meaning and content of national belonging will be transformed as the structural basis of national citizenship continues to be undermined”. Such notions have important implications for the practices and processes of citizenship within and beyond states, as they may be able to make citizenship more relevant and inclusive for migrants and those in diaspora with complex and ambiguous relations to the state. At the same time, however, feelings of national belonging to the de/re territorialised nation and/or homeland continue to be important for many in diaspora and this cannot be ignored. 
This paper adds to such debates on citizenship and its relationships to national identity by putting forward the concept of pragmatic citizenship, or citizenship that is sought, acquired and negotiated for pragmatic and strategic reasons and can result in dual or multiple feelings of belonging and attachment as well as de/re-territorialisation. It may be seen as similar to the notion of 'instrumental citizenship' discussed by Aguilar (1999) which denotes the fact that home states accept the fact that although their émigrés may have citizenship and formal belonging in another state, they still are emotionally attached to their homeland and make allowances for this. In this way, they are still treated as part of a nation that is spread out and de-territorialised. Such a notion of citizenship is also reminiscent of the work by Ong (1999) on flexible citizens, whereby there is the acquisition of multiple passports as a means of security as well as the work of Waters (2003) where Canadian citizenship and the 'spreading out' of families is also used strategically in the education of Chinese migrants. Such a focus on the importance and use of passports is central to notions of pragmatic citizenship, whereby the strategic acquisition of citizenship is equated with the acquisition of a passport for security, social and economic reasons, rather than strong or exclusive belonging to the host state.

This paper attempts to illustrate that such pragmatic citizenship can have varying repercussions in terms of perceptions of the relationships between citizenship and national identity because it may depend on where such perceptions are directed: the host state or the homeland. Pragmatic citizenship may encourage the decoupling of the relationships between citizenship and national identity in the host state, whereby migrants and those in diaspora do not possess strong feelings of belonging to that state. This may also lead to feelings of ambivalence, in-between-ness as well as the negotiation of dual or 
multiple attachments to place and territory. However, this can also lead to the coupling of the relationships between citizenship and national identity in the homeland or future state, particularly if the group in question involved in nation-state building. Pragmatic citizenship may take on special significance for such groups because it can be seen as a way to gain citizenship status and the rights and privileges this affords without the need to fully belong to the host state and without the need to 'let go' of attachments to the homeland. In turn, this may also fuel perceptions of the nature of citizenship and its relationships to national identity in the homeland and/or future state that are not necessarily exclusive.

Before an in-depth discussion of empirical evidence to explore such issues, it is necessary to examine the complexities of citizenship and legal status of Palestinians in Greece. This, and the contextual background that follows, will help illustrate why the relationships between citizenship and national identity are important to these exilic and diasporic Palestinians as they engage in politicised discourses of nation-state building and self-determination that are often based on negative perceptions of statelessness and injustice.

\section{Palestinian perceptions of injustice and legal status}

According to the Palestinian representation in Greece, there are roughly 4000 Palestinians in Greece; most live in Athens, but they are also spread around Greece in cities such as Thessaloniki and Patras. The arrival of the Palestinian diaspora in Athens is relatively recent. As a result, most Palestinians in Athens are first-generation migrants. Its first members started arriving in Greece in the late 1960s. There are various Palestinian 
'groups' in Greece. Some are currently students, some came as students, finished their studies and found work, others came as students and did not finish. Others arrived as skilled or unskilled workers; the former can be split into those who work for foreign owned companies in Greece and who may feel their presence in Greece is more transient and insecure and those who do not (for more on the different groupings of Palestinians in Greece, see Shawa, 2005).

Many are not Greek citizens as Greek citizenship is granted on a jus sanguinis basis and is closely guarded (Rozakis, 1996) and is often difficult to obtain as a result (Fakiolas, 1999). Therefore, many are dependant on work and residence permits in order to live there and with often-difficult legal statuses see the acquisition of Greek citizenship as a desirable and pragmatic solution to this. Palestinians constitute a diverse group of people and there are differences in their legal status, which often depends on whether they originated from what is now Israel or the West Bank/Gaza and where, if anywhere, they have moved to before coming to Greece. This research reveals that Palestinian residency and official statuses in Athens are complex, often confusing and consequently difficult to generalise about. Therefore, this background information is not exhaustive but an introduction to illustrate Palestinian perceptions of injustice and discrimination as a result of statelessness and exile.

Due to fighting during 1947-1948 and the creation of the state of Israel, the majority of Palestinians fled or were expelled from the area that is known as historical Palestine, mainly into the Middle East. ${ }^{2}$ For example, those from what is now is now Israel who went to Lebanon and Egypt after 1948, were given travel documents in these

\footnotetext{
${ }^{2}$ For an overview in terms of their citizenship status in the Middle East and beyond see Karmi and Cotran (1999).
} 
countries, but not citizenship, which often makes travelling difficult, although naturalisation amongst Palestinians in Lebanon is increasing (Peteet, 1996, cited in Lindholm Schulz, 2003: 54). Lindholm Schulz (ibid.) also stresses that "exclusion and marginalisation remain the most prominent feature of the Palestinian experience in Lebanon". ${ }^{3}$ Those who went to Jordan form a large percentage of the population there and were given Jordanian citizenship, with the exception of those from Gaza, who hold Egyptian travel documents (ibid.: 46). From 1994, the Palestinian National Authority issued identity cards to Palestinians in the West Bank (see Kelly, 2006 for more on this). A proportion also stayed in Israel, becoming Israeli citizens and forming around $20 \%$ of the population. Secondary waves of migration also saw many Palestinians move to the Gulf States (although the Gulf War in 1990/1991 forced many to move again) and North America.

It has to be noted that the definition of Palestinians as refugees can be problematic. Although most Palestinians in Athens are not registered refugees, they may come from refugee families, who may or may not be registered with the United Nations Relief and Works Agency (UNRWA); alternatively, they may view all Palestinians as displaced refugees in a more general sense. According to Lindholm Schulz (2003: 35, 36), UNRWA was created in 1950 to 'rehabilitate' Palestinian refugees, which also means they are excluded from the 1951 Geneva Convention on the State of Refugees. Therefore, they are not fully protected by any international body. There are also Palestinians who have not been included in UNRWA definitions of refugee status such as those who fled to countries where UNRWA does not operate. For the purposes of this

\footnotetext{
${ }^{3}$ For more information on Palestinians in Lebanon see, for example, Shiblak (1997) and Sayigh (1994).
} 
paper, it suffices to say that many Palestinians in Athens perceive the problems they face in terms of legality, movement, displacement and discrimination could potentially be solved by the creation of a Palestinian state.

The ability of Palestinians to enter and reside in Greece aptly illustrates the issues surrounding mobility, legal status and consequent feelings of insecurity and injustice. Entering Greece students appears to have been a relatively easy for Palestinians. As Layla, explains: "Greece was the only country that would accept me...my parents were told at the time by friends that it was very easy to get a student visa to come to Greece, so we went to the Greek Embassy in Abu Dhabi where we were living at the time and they gave me a student visa for 3 months". The choice of Greece as a destination for Palestinians students may be partly explained by the popular (and to a lesser extent, political) support the Palestinian cause has tended to receive in Greece (Smith, 2002). At the same time, however, despite this support, evidence from this research suggests that Palestinians without Greek (or other Western country) citizenship status are often plagued by feelings of insecurity, despite the fact that many appear to enjoy living in Greece. For example, Lina stresses that: "Now, that I have the Greek passport, I am okay, but before it was a big problem”. Residency issues are problematic and as Layla points out: "we are at the mercy of Greek law; if it changes, we are lost".

This research suggests that Palestinians from the West Bank and Gaza face considerable restrictions in travelling, both within the Middle East and elsewhere if they hold a Palestinian passport. It has to be noted that Palestinians in Athens perceive this passport differently. Some see it as a legitimate and official document, legalising their status as Palestinian. Others are more pessimistic, arguing that it is a fake document that 
does not mean very much because Israel controls who is and is not allowed to have one, which for them, nullifies its validity. Many also feel that they are always singled out and discriminated against because they are stateless, which highlights them as different. For example, Mustafa says: “I have a Palestinian passport. It’s not like a proper passport, it’s more of a travel document; it's difficult to get a visa with it (He shows it to me. On it, the words 'Palestinian passport' and 'travel document' are both written). It's hard because with every application you make, every procedure, you are in another category; you're singled out as different, needing special treatment”.

Other Palestinians, particularly those who moved to Egypt and Lebanon, also emphasise their lack of rights as well as restricted movement. Ahmed, whose family settled as refugees in Lebanon after 1948, but who himself lives in Greece as a result of his job at a foreign owned company, describes the situation and the material consequences for his present documentation, which he himself finds confusing:

We [Palestinians] have travel documents in Lebanon, Syria, Jordan and Egypt - they gave them to Palestinians who left in 1948 and then in 1967 they give another travel document but whoever registered in Lebanon in 1948, they have these travel documents and those who left in '67 don't have the travel documents that we have.

Interviewer: They have something different?

Ahmed: Actually, I don't know exactly. For example, they have the right to go back to the West Bank. We don't have this right even with these peace negotiations...I carry a 
Syrian passport. It was granted to my dad by a general who became the president of Syria and he granted very few of them, so he's carrying a Syrian passport, my son, but he knows that he is not Syrian. You know he asked me, how come I have a Syrian passport when you say I am Palestinian. Sometimes you feel it must be so frustrating for him. He cannot understand, it's very difficult.

Many interviewees from historical Palestine have no right to go to the West Bank and Gaza, let alone visit what many see as their homeland (which now encompasses Israel). For example, Faeq stresses his anger at what he perceives as the injustice of this: "I don't have the right as a 1948 refugee even to ask for the Palestinian passport. I can't get it...because you know that passport is better than what I'm having now, the Lebanese travel document. It's ridiculous and that's why they don't want to give us the right to go back there”. Both quotations above also highlight the complexities surrounding Palestinian legal status as well as the number of categories from which Palestinians have the potential to be included and excluded. The mobility restrictions they face are well illustrated by Layla, whose family are refugees who originally moved Lebanon but whose immediate family now live in Abu Dhabi, as she responds to a question on how easy it is for her to travel:

(Laughs) It's impossible! Because I remember, before 6 or 7 years, my friends - they were immigrants to Canada, so I just wanted to go there to Canada. They gave Hassan [Layla's son] the Greek passport, this is another story (laughs) - they told me that my son could go without a visa, but that I do need a visa. Okay, I applied for a visa but they 
refused to give me one so I couldn't go to see my friends. Also, if I want to visit my parents in Abu Dhabi, I need a visa but Hassan doesn't. My parents applied to go to Canada to but they didn't get in but my brother and sister did. There are a lot of difficulties for Palestinians. When we talk to other nationalities, they always ask are you crazy? Nobody can believe our situation.

The complexities of diasporic Palestinian legal and citizenship status make their future inclusion into a Palestinian state potentially problematic, especially if they wish to return. Although diasporic Palestinians not originally from the West Bank and Gaza (as well as those from these areas originally who have moved away) may be allowed Palestinian citizenship in an eventual Palestinian state, they may not want to relinquish the Right of Return to their original historical homeland, an issue that many Palestinians in Athens have started thinking about. The Right of Return of Palestinian refugees forms part of the Palestinian cause and it highlights the need to deal with displaced Palestinian refugees, particularly those living in the Middle East, who, according to the United Nations, have the right to return to the homes they were originally displaced from.

Linked to this is the fact that there are some Palestinians in Athens who find the acquisition of non-Palestinian citizenship as politically disloyal to the Palestinian cause and are quite happy to remain 'in-limbo' indefinitely, without citizenship, in order to highlight the fact that they are stateless and displaced Palestinian refugees with the Right to Return to (historical) Palestine. This is legitimised by international law (for more on this see Al-Qasem, 1999), but is problematic within a two-state solution, as Israel is unlikely to allow such refugees to return to their original homes. According to 
Rabinowitz (2001: 82), for example, the Oslo-Wye process of reconciliation between Israel and Palestine states that a two state solution is viable but assumes that only those Palestinians originally from the West Bank and Gaza will be entitled to citizenship in a Palestinian state. This means that "all Palestinians living elsewhere...are somehow expected to merge somehow into their current host societies”. Such a solution also means that refugees in diaspora from what is now Israel will not be able to return to their original homeland. The issue of not being able to return can often be frustrating for those in diaspora to deal with. For example, Jamal discusses his own feelings on the matter:

Interviewer: And if a Palestinian state is created, will Palestinians such as yourself in the diaspora have the right to go and live there if you want to?

Jamal: This is under negotiation. How can they have the right to say and decide whether I am Palestinian or not? This means they can take your rights and, therefore, your hope, away from you; somebody is doing your negotiation on your behalf and they will pay you money. What is this? Who has the right and the idea to do this? And nobody can claim that it [the land] is not ours...I can't imagine what will happen to me if they claim that I am not Palestinian. So what kind of compensation can they give to me and by whom?

Although he lives in Greece, Jamal's family moved to Egypt from Gaza and his testimony below illustrates the difficulties he has encountered as a result: 
I have Egyptian travel documents - they are the worst travel documents used by the Palestinians because actually we don't have the right to go back to Egypt and it causes us a lot of problems until now. I have been in Greece for almost 9 years and I have been given residence by my job for the last 8. Suddenly, they started saying that I am not Palestinian. The authorities... started saying that I was not Palestinian, but Egyptian, but I'm not Egyptian and they said that I have to pay IKA [social insurance] because there is an agreement between the government and Egypt that citizens of both countries pay IKA in both countries so after 8 years they realised that I was not Palestinian although on my permit it wrote Palestinian, suddenly they said, no you are Egyptian and I have to pay the IKA for the last 8 years and double the amount as a penalty, which is something like 150,000 dollars, which of course I couldn't pay so for the last 9 months I am staying in Greece without legal status, I cannot move or travel, I cannot go to my family who live in Egypt and I'm stuck and I don't know if it will be solved or not. If I am caught, I could be deported to where I don't know, because there is no country I can go to. I don't really belong anywhere; there is nowhere I can go to legally. I am trapped here; it's a prison for me. This is my situation for the last 34 years - this is how old I am. Because people see you as someone without a state, without citizenship and they don't want to take you and the ones that take you see you as a burden.

Such realities and perceptions of insecurities, injustice and suffering seem to form a significant part of the need to have an official Palestinian state, which many interviewees feel is important in order to deal with statelessness and the problems and insecurities they perceive this causes. As Sana states, "Palestinians outside Palestine are often left with 
nothing, nothing formal, no citizenship...if you can't travel as a result or do the things you want to do, you will say why me? It's not fair”. Therefore it is unsurprising that there is a perceived need amongst Palestinians in Greece to remain politicised, attached to Palestine and to feel Palestinian regardless of citizenship status. Many also feel that the political need to link future statehood with a Palestinian 'identity' is important even as they acquire pragmatic citizenship. However, this does not necessarily prevent them from feeling ambivalent about their notions of home and belonging (see Mavroudi, forthcoming) or from having dual or multiple feelings of attachment.

\section{Palestinian acquisition of pragmatic citizenship}

This research reveals that for Palestinians in Athens, pragmatic citizenship appears closely related to the holding of passports that enable travelling and afford more protection and security. As Lindholm Schulz (2003: 188) points out: "what appears to be significant to Palestinians living in Western countries is the sense of security provided by the passport and by the political system”. The acquisition of a passport through pragmatic citizenship proves official belonging to those who are stateless but it increasingly does not have to necessitate strong or exclusive feelings of national belonging to the country whose citizenship has been obtained but may encourage or allow for hyphenated identities, multiple or dual attachments/feelings of belonging. This does not necessarily mean that pragmatic citizenship is an inferior form of citizenship but that it is strategic and allows for a variety of outcomes in terms of feelings of home, belonging, attachment and territorialisation, whilst helping to deal with complex legal status and feelings of discrimination and injustice. 
The strategic element of pragmatic citizenship is illustrated, for example by Layla:

When I get the Greek nationality, maybe I'll go back to live with my parents ... So, if I am able to find a good offer in Abu Dhabi I will go...If I go now, maybe I can, maybe I can't, I haven't looked in to the possibility. As a European, I will gain triple the money. If I go as a Palestinian - my brother, he is married, he works there. He's a human resource manager. If he works with his Palestinian travel document, he would gain 3 or 4,000 but with his Canadian nationality he earns about 13,000 just because he's Canadian, it's ridiculous. He said to me, please don't come back until you take the Greek nationality, because otherwise you will not live like us and you will live like you live in Greece, with little money. With our names, our nationality, we cannot live a good lifestyle.

Layla is also acutely aware of the benefits of Greek citizenship for her son and her account of the difficulties encountered whilst trying to secure this also illustrate the importance attached to pragmatic citizenship as well as the problems Palestinians face:

Let me tell you the story of my son - how we got his passport. I am Palestinian with the Lebanese travel documents. My ex-husband, he's Palestinian with Syrian travel documents. I don't have the right to give my son the Lebanese travel documents. I mean I can't put his name on my passport. Also my ex-husband, he lost his civil rights in Syria, because he was against the government so he had the Yemeni passport. These passports were given to the PLO as presents to make life easier for these people in the PLO but 
they were not allowed to give them to their children or their family so as you can understand, the conclusion of this was that my son was without a nationality.

Interviewer: Where was he born?

Layla: Here in Athens...something in the Greek law says that if a person was born in Greece and he can't get either his mother's or his father's nationality, so he can get a Greek nationality, so this is what happened. It was very difficult for me for 2 and half years until he got it; it was a nightmare for me. So for 2 and half years I couldn't travel, I couldn't go anywhere; he had no papers, just the birth certificate. But all this happened, and now I'm really happy that this happened because he got a good passport; he can go and do whatever he wants; it's good for his future.

The acquisition of pragmatic citizenship from Western countries increases access to Israel/Palestine, an issue many Palestinians in Athens find important. Many want to be able to go back, either to visit or to live and for many this is an active strategy that is pursued. As Ibrahim explains:

We cannot go there; it's difficult for us to go, that's why we need to get Greek citizenship - so that we can go there...I wouldn't have a problem getting it. Getting it doesn't change where you're from and who you are though. I would still feel Palestinian. I could become Greek and get involved here and do everything Greeks do but people can belong to two countries. 
Ibrahim reiterates the fact that pragmatic citizenship can encourage feelings of dual attachment and belonging, whereby he feels it is acceptable to become a Greek citizen and belong there whilst still maintaining his feelings of being Palestinian which are very strong and which he does not want to let go of. Sa'id also usefully describes the acquisition of pragmatic citizenship in other Western countries: "Palestinians go to these countries, they say they're going to stay 3 years. If they have problems with the Israeli government, prosecution or anything, they know that when they leave that they cannot go back to see their family with the Palestinian passport they have. So then they ask for asylum and as soon as they get the citizenship they go back”. Sa'id is referring to the general situation in Western countries, not Greece, as claiming asylum in Greece is an arduous process and few Palestinians have been granted it. He himself has Jordanian citizenship, but points out: "I'm not allowed to go. I have to get another citizenship in order to go.” His personal strategy to overcome this is studying political science to become a diplomat, in which case he believes “the Israelis won’t be able to touch” him. Because access to Palestine/Israel is controlled by Israel, Palestinians need Western state citizenship before they are allowed to enter their homeland and this is something that they often find unfair.

Pragmatic citizenship can facilitate access to the homeland without the need to form exclusive or full attachments to either the host country or homeland. This is another reason why pragmatic citizenship in a Western state is seen as so important. It does not stop Palestinians from being passionately attached to Palestine as a territorialized homeland to belong to, whether they have been or lived there or not and whether they might want to return there to live or not. What is less clear is how Palestinians in diaspora 
will react of they are not automatically entitled to citizenship in a future state, or they are not given the right to return and therefore, may feel excluded. Jamal illustrates these issues well:

I don't want to give up my belonging, that I am Palestinian. I love my country; I love being Palestinian. I love my homeland. This is something I cannot give up. If they would give me any nationality or any kind of compensation I would not give it away because it's not for sale; it cannot be changed. It's a human right to feel that you belong to some place.

Jamal does not feel that the acquisition of pragmatic citizenship is problematic because he will continue to feel Palestinian whether or not he is allowed to return to live there. Likewise, Tariq, who is a Greek citizen, and has been living in Greece for over twenty years and is married to a Greek, believes his feelings of being Palestinian "will never change. My roots, my origins are Palestinian. And my papers write this, I'm not just saying it”. This is despite the fact that he, like other Palestinians with Greek citizenship who have lived there for a considerable amount of time may also feel Greek to a greater or less extent. Even Palestinians in Greece who are more ambivalent about their notions of home and belonging maintain that they still feel Palestinian even if they may also feel Greek, Arab, or a mixture.

The perceived need for a politicised Palestinian identity to help ensure that Palestinians achieve statehood is seen as paramount. This belief can be summarised as "the creation of a Palestinian land for Palestinian people, where they can be free and have 
all their rights" (Abbas) and "We are entitled to an independent Palestinian state. We are entitled to an identity" (Rafat). Such feelings of needing to hold onto a Palestinian identity are also triggered by insecure legal status and feelings of marginalisation and discrimination, as Faeq points out: "they [the Greek authorities] don't write that I am Palestinian, when I am. They don’t have a Palestinian category; we don't exist”. Among some respondents, this appears to have also led to a need to prove that they are Palestinians as a defensive mechanism. Mahmud, for example, stresses that he is a “genuine Palestinian. I have a Palestinian identity card and passport” (italics added).

Lindholm Schulz (2003: 88) explains that: "the Palestinians are constantly faced with suspicion, harassment and exclusion because they cannot prove a national identity, a citizenship legally inscribed in their passports". However, she also claims that "the condition of being Palestinian...is to move" (ibid.: 87). Therefore, because they are in exile and stateless, they feel they have to acquire pragmatic citizenship which can lead to feelings of belonging in the host society. However, at the same time, because there is no Palestinian state, such belonging can be ambivalent and be seen as problematic and is often accompanied by politicised feelings of 'Palestinian-ness'. For example, they may feel 'at home' in Greece, but feeling Palestinian and belonging to Palestine often comes first because of the current situation and unresolved conflict there. However, what is important about such attachments is that they are not necessarily exclusive of others, but are based around the need to belong to territory they see as rightfully and historically theirs, as the last section of this paper illustrates. Living in diaspora 'here' but belonging 'there' or 'here/there' has allowed some Palestinians in Greece to formulate visions of 
statehood and citizenship that are based on 'radical inclusiveness' ${ }^{4}$ but without letting go of feelings of national identity and belonging that are constructed in non-exclusive terms.

\section{Future statehood, citizenship and belonging}

Despite the potentially exclusionary aspects surrounding nationalism and its relationship to citizenship and the state, the state appears to be a major factor in the governing and organising of contemporary society. Some have argued that the nation-state remains important (Triandafyllidou, 1998; Marden, 1997; Ong, 1999), as it is perceived as the main way in which people can obtain rights. Therefore, it is unsurprising Palestinians cling onto statehood and self-determination as a way to deal with their current statelessness. However, although there is always the propensity for us/them relationships to occur in the process of state-building that arise out of extreme notions of national identity and there are a few Palestinians in Athens who see the differences between Jews and Arabs in negative terms, there are also numerous Palestinians who stress that although they, as Palestinians, deserve a state to belong to, the lives of Jews and Arabs in historical Palestine are and always have been interconnected.

In turn, this has prompted some of these Palestinians to promote a one-state solution to the Palestinian-Israeli conflict, in which both Jews and Arabs live together in one state, which can be seen as 'radically inclusive'. It is hard to pinpoint why exactly these Palestinians have to come so such a conclusion, but it may be that time spent in the West has a role to play. However, as these Palestinians may not have access to political institutions in Greece, let alone the West/Bank and Gaza, it is hard to see how such

\footnotetext{
${ }^{4}$ I am grateful to an anonymous referee for suggesting the notion of 'radical inclusiveness'.
} 
positive notions will be able to become a form of political transnationalism and affect the current impasse in the region.

The partial and complex dismantling of the exclusive and problematic aspects of the relationships between citizenship and national identity appear related to transnational and/or diasporic belonging as well as cross-border connections. Feeling 'here' and 'there' or 'in-between' as a result of living in diaspora can help break down normalised associations between national or ethnic identity, citizenship and statehood despite the perceived need of political attempts to connect them for the sake of advocating the Palestinian cause and self-determination.

A positive repercussion of the realisation that the relationships between citizenship and national identity are potentially unstable, arbitrary and do not have to be exclusive, can be seen in these Palestinian understandings of the lives of Jews and Arabs as intricately connected within a shared homeland. Some Palestinians feel that a one-state solution to the present situation within historical Palestine, in which Jews and Arabs live together and tolerate their differences and those of others too, is the best solution. This may especially be the case for Palestinians who are originally from what is now called Israel, as illustrated by the testimonies below by two men whose families are from the north part of the land that now constitutes Israel. For example, in response to a question on hopes for the future in Palestine, Faeq says:

I think that the future should be a mixture of the 2 states; I think we should live together. We are both mixed anyway; we are joined whether we like it or not, so we should have a country for everyone. Eventually I think this will happen. Many Palestinians and Israelis 
would like this. There are a few people in Israel who control everything with absurd ideas.

Ahmed also appears convinced that such a solution is possible, as do other Palestinians in Athens:

The ultimate goal, I think should be all of [historical] Palestine for both Jews and Palestinians together. I think that if they create a Palestinian state in a two-state solution, it will be so small that it won't survive. It will be too weak. It won't be practical and it will not be a fulfilment for all the hopes we have had for all this time. My ultimate hope is to be able to go to Jaffa and to anywhere and everywhere there in historical Palestine with the same rights as the Jews; to have equal rights with them, so that we can all live together. However, a Palestinian state is a step in the right direction, but I am not hopeful that there will be a state. There will only be isolated ghettoes or islands. This Apartheid wall that they are building has to be pulled down.

Interviewer: Would you be happy with a two-state solution?

Ahmed: Well, I think, let's live together and create a democratic state, where both Israelis and Palestinians can live together. Israel will not go away; we have to live together, with everyone enjoying religious freedom. And I think that many others share my views. It's not easy to forget where you come from or all the problems and the suffering you and your people have had to go through. I really don't think a two-state 
solution will work because what you will get and what you are already getting is the creation of Palestinian islands or ghettoes in an Israeli sea where you need a ferry to cross from one island to the other. It is impossible.

Ahmed's use of the word 'ghettoes' is interesting; he purposefully relates present Palestinian suffering, injustices and hardship that he feels Israelis are responsible for with the ghettoes Jews themselves suffered in. At the same time, however, his rationale in using such an argument is important, because it highlights the interconnected lives and fates of Jews and Palestinians within a highly contested, problematic piece of land that is emotionally and symbolically invested (Shapiro, 2000).

The views of these Palestinians also help stress that "Palestinian and Israeli, Arab and Jew are not natural categories, but politically contingent categories that are forever shifting and changing in meaning and implications" (Kelly, 2006: 103). An acknowledgement of this can make power-sharing solutions such as the one-state proposal and bi-nationalism gain support. For example, Yiftachel and Yacobi (2002) have discussed Jerusalem/al-Quds becoming a shared bi-national city, Karmi (1999) has advocated a bi-national state, Iris Marion Young (2005) has put forward the notion of self-determination as non-domination, Pappe (2004) has outlined Palestinian and Israeli histories and most recently, Abunimah’s book (2006) proposes a one state solution.

In addition to such notions of sharing and inclusiveness, boundary deconstruction is also seen as important. For example, Mustafa who is originally from the West Bank, also points to the importance of removing boundaries within a future state: 
I think there needs to be a solution that can satisfy both parties. So many innocent people are dying. We are fighting for the right to live, for our human rights. The thing is you can't get rid of a people or have one country win at the expense of the other. We have accepted unjust negotiations like Oslo and the road map. We want peace, because I don't know how long the Palestinians can take it.... You know, I believe there should be no borders anywhere. They don't do any good. They are like obstacles. People should be free to move around wherever they want.

Interviewer: It's ironic then, isn't it that this whole conflict is about borders, defining concrete borders and a defined territory called Palestine. Aren't borders important in some contexts?

Mustafa (Silence): Yes, you need to define areas, but they shouldn't be restrictive or limit travelling.

The material and symbolic dismantling of borders and of negatively constructed differences between people and the consequent recognition of a joint destiny within the same land are very powerful notions. The potential, however, for the creation of new boundaries, tensions and constructions of difference is always present. For Palestinians in Athens to come to such conclusions involves an understanding of the importance of diversity, tolerance and the multiplicity of situated and dynamic identities, as well as the decoupling of citizenship and national identity within a future Palestinian state or national identity that is constructed in non-exclusive ways. There is more work to be done to 
explore the repercussions of living in the West on notions of future citizenship and whether this constitutes a form of political transnationalism that has the power to help resolve the Palestinian-Israeli conflict in ways that are not based around exclusivist notions of the relationships between citizenship and national identity but still allow people to belong to a territorialised homeland.

\section{Conclusions}

This paper has examined constructions of the relationships between national identity and citizenship in relation to the Palestinian diaspora in Athens. It stresses the need for nuanced and careful understandings of the relationships between those exiled in diaspora and their homeland/host countries, particularly for those who are politicised, stateless or who have ambiguous relations to the state in which they currently live (and which may also be problematic in relation to a future state). As Nagel and Staeheli (2004: 4) stress: "geographies of community, identity and citizenship are more complex and are in greater flux than much of the contemporary debate [on these issues] implies”. This paper has illustrated that due to statelessness and complex legal status Palestinians in Athens have strategically acquired pragmatic citizenship out of necessity, which enables differing forms of belonging that are not necessarily exclusive but that may be constructed and deconstructed for particular politicised and material reasons.

Although notions such as Soysal's (1998) 'post-national membership' and Tambini's 'post-national citizenship' (2001) may be important for those living in diaspora, pragmatic citizenship may be more relevant at times as it takes into account the need to belong to a defined but de/re territorialized nation and/or have multiple 
attachments and the importance attached to states as the providers of citizenship status. Above all, it stresses the need for the decoupling of exclusive relationships between citizenship and national identity. The pertinence of nationalism and the institutional constraints imposed by countries (Bailey et al. 2002) and how the lives of those in diaspora are affected as a result must be recognised and cannot be ignored. However, as Fine (1999: 154) also reminds us, "nationalism is a fickle beast. In its best moods, it liberates human beings from colonial oppression and unites people previously fragmented but it also excludes those deemed not to belong and demands the active assent of its 'own' nationals". At the same time, despite their potential for exclusivities, it also has to be remembered that national identity and nationalism are malleable, complex and dynamic constructions that are contested through time and space (Armstrong, 1998).

Those in diaspora, as citizens or not, may be in a difficult position as they realise the importance of cross-border connections and boundary transgressions, but at the same time are limited and hindered by the borders protected and enforced by nation-state institutions who may still try to protect citizenship that is based on potentially exclusive notions of national identity. However, this paper has shown that despite the jus sanguinis nature of Greek citizenship, its acquisition (and potential acquisition) by Palestinians does not necessitate them to feel as if they are fully Greek. Palestinians in Athens are aware of (and utilise) pragmatic citizenship that in turn allows them to construct strong notions of belonging and attachment that may be singular, dual or multiple and that allows them to obtain rights in the host country. Pragmatic citizenship can also lead to inclusive visions of self-determination and future citizenship in a one-state solution in which Jews and Arabs live together and where all Palestinians displaced may be included 
and given the Right to Return. Given the struggles in this part of the world, such perceptions and notions of citizenship as pragmatic that allow for the deconstruction of exclusive relationships between citizenship and national identity are useful for long-term and future scenarios of peace in the region.

\section{Acknowledgements}

I am grateful to the Economic and Social Research Council (ESRC), who funded the research this paper is based on (PTA 030-2002-00600). I would like to thank Cheryl McEwan for her support and guidance and three anonymous referees for their invaluable suggestions and comments.

\section{References}

Abunimah, A., 2006. One Country: A Bold Proposal to End the Israeli-Palestinian Impasse. New York: Metropolitan Books.

Aguilar, F.V.J., 1999. The triumph of instrumental citizenship? Migrations, identities and the nation-state in Southeast Asia. Asian Studies Review (23), 307-336.

Al-Qasem, A., 1999. The right of return in international law. In: Karmi, G., Cotran, E. (Eds.), The Palestinian Exodus: 1948-1998. Reading, Ithaca Press, pp.123-151.

Anderson, B., 1983. Imagined Communities. London, Verso. 
Armstrong, W., 1998. Belonging, ethnic diversity and everyday experience: co-existing identities on the Italo-Slovene Frontier, Transnational Communities Research Working Paper WPTC-98-05.

Bailey, A.J., Wright, R.A., Mountz, A., Miyares, I., 2002. (Re)producing Salvadoran transnational geographies. Annals of the Association of American Geographers 92 (1), $125-144$.

Benhabib, S., 2004. The Rights of Others: Aliens, Residents and Citizens. Cambridge, Cambridge University Press.

Castles, S., Davidson, A., 2000. Citizenship and Migration: Globalization and the Politics of Belonging. Basingstoke, Macmillan.

Carter, S., 2005. The geopolitics of diaspora. Area 37 (1), 54-63.

Croucher, S.L., 2004. Globalization and Belonging: The Politics of Identity in a Changing World. Maryland, Rowman and Littlefield.

Davis, U., 1997. Citizenship and the State: A Comparative Study of Citizenship Legislation in Israel, Jordan, Palestine, Syria and Lebanon, Reading, Ithaca Press.

Fakiolas, R., 1999. Greece. In: Angendedt, S. (Ed.), Asylum and Migration Policies in the EU. Berlin, Research Institute of the German Society for Foreign Affairs. 
Faist, T., 2000. Transnationalization in international migration: implications for the study of citizenship and culture. Ethnic and Racial Studies (23), 189-222.

Faulks, K., 2000. Citizenship. London, Routledge.

Fine, R. 1999. Benign nationalism? The limits of the civic ideal. In: Mortimer, E., Fine, R. (Eds.), People, Nation and State. London, IB Taurus, pp. 149-161.

Gilroy, P., 1999. It ain't where you're from, it's where you're at: the dialectics of diasporic identification. In: Vertovec, S., Cohen, R. (Eds.), Migration, Diasporas and Transnationalism. Cheltenham, Elgar, pp. 280-292.

Glick Schiller, N., Fouron, G., 2001. Georges Woke Up Laughing: Long Distance Nationalism and the Search for Home. Durham and London, Duke University Press.

Ip, D., Inglis, C., Wu, C.T. 1997. Concepts of citizenship and identity among recent Asian immigrants in Australia. Asian and Pacific Migration Journal (6), 363-384.

Isin, E.F., Wood, P.K., 1999. Citizenship and Identity. London, Sage.

Karmi, G., 1999. Concluding vision: a return to Israel/Palestine? In: Karmi, G., Cotran, E. (Eds.), The Palestinian Exodus: 1948-1998. Reading, Ithaca Press, pp. 243-252. 
Karmi, G., Cotran, E. (Eds.), 1999. The Palestinian Exodus: 1948-1998. Reading, Ithaca Press.

Kelly, T., 2006. Documented lives: fear of the uncertainties of law during the second Palestinian Intifada. Journal of the Royal Anthropological Institute 12, 89-107.

Khalidi, R., 1997. Palestinian Identity: The Construction of Modern National Consciousness. New York, Columbia University Press.

Lindholm Schulz, H., 2003. The Palestinian Diaspora: Formation of Identities and Politics of Homeland. London, Routledge.

Marden, P., 1997. Geographies of dissent: globalisation, identity and the nation. Political Geography 16 (1), 37-64.

Mavroudi, E., 2007. Learning to be Palestinian in Athens: constructing national identities in diaspora. Global Networks. 7 (4), 392-411.

McEwan, C., 2000. Engendering citizenship: gendered spaces of democracy in South Africa. Political Geography (19), 627-651.

Nagel, C., Staeheli, L., 2004. Citizenship, identity and transnational migration: Arab immigrants to the United States. Space and Polity 8 (1), 3-23. 
Ong, A., 1999. Flexible Citizenship: The Cultural Logics of Transnationality, London and Durham, Duke University Press.

Painter, J., Philo, C., 1995. Spaces of citizenship: an introduction. Political Geography 14 (2), 107-120.

Pappé, I., 2004. A History of Modern Palestine: One Land, Two Peoples, Cambridge, Cambridge University Press.

Rabinowitz, D., 2001. The Palestinian citizens of Israel, the concept of trapped minority and the discourse of transnationalism in anthropology. Ethnic and Racial Studies 24 (1), 64-85.

Rozakis, C. L., 1996. The international protection of minorities in Greece. In: Featherstone, K., Ifantis, K. (Eds.), Greece in a Changing Europe: Between European Integration and Balkan disintegration? Manchester, Manchester University Press, pp. 95117.

Sayigh, R., 1994. Too Many Enemies: The Palestinian Experience in Lebanon. London and New Jersey: Zed Books.

Shapiro, M. J., 2000. National times and other times: re-thinking citizenship. Cultural Studies 14 (1), 79-98. 
Shawa, S. 2005. Palestinians in Greece: same sense of belonging, diverse communities. In: Shiblak, A., (Ed.), The Palestinian Diaspora in Europe: Challenges of Dual Identity and Adaptation. Shaml (The Palestinian Refugee and Diaspora Centre) and the Institute of Jerusalem Studies. Available online at http://www.rsc.ox.ac.uk/PDFs/Shiblak.pdf

Shiblak, A., 1997. Palestinians in Lebanon and the PLO. Journal of Refugee Studies 10 (3), 261-274.

Skrbis, Z., 1999. Long-Distance Nationalism: Diasporas, Homelands and Identities. Aldershot, Ashgate Publishing.

Smith, H., 2002. Greece Unites in Condemnation of Israel. The Guardian Newspaper, $12^{\text {th }}$ April.

Smith, A.D., 1999. The nation: real or imagined. In: Mortimer, E., Fine, R. (Eds.), People, Nation and State. London, IB Taurus, pp. 36-42.

Soysal, Y., 1998. Towards a postnational model of membership. In: Shafir, G. (Ed.), The Citizenship Debates: A Reader. Minneapolis, University of Minnesota Press, pp. 189221.

Stein, R.L., Swedenburg, T., 2004. Popular culture, relational history, and the question of power in Palestine and Israel. Journal of Palestine Studies 33 (4), 5-20.

Tambini, D., 2001. Post-national citizenship. Ethnic and Racial Studies 24 (2), 195-217. 
Triandafyllidou, A., 1998. National identity and the 'Other'. Ethnic and Racial Studies 21 (4), 593-612.

Waters, J., 2003. Flexible citizens? Transnationalism and citizenship amongst economic migrants in Vancouver. The Canadian Geographer 47 (2) 219-234.

Wimmer A., Glick Schiller, N., 2002. Methodological nationalism and beyond: nationstate building, migration and the social sciences. Global Networks 2 (4), 301-334.

Yiftachel, O. and Yacobi, H., 2002. Planning a bi-national capital: should Jerusalem remain united? Geoforum 33 (1), 137-145.

Young, I.M., 2005. Self-determination as non-domination: ideals as applied to Palestine/Israel. Ethnicities 5 (2) 139-159. 